\title{
Alternative Resources for Renewable Energy: Piezoelectric and Photovoltaic Smart Structures
}

\author{
D. Vatansever, E. Siores and T. Shah
}

Additional information is available at the end of the chapter

http://dx.doi.org/10.5772/50570

\section{Introduction}

Energy harvesting is the process of extracting, converting and storing energy from the environment that can also be described as a response of smart materials when they are subjected to an external stimulus such as pressure, vibrations, motion and temperature emanating from wind, rain, waves, tides, light and so on. The efficiency of devices in capturing trace amounts of energy from the environment and transforming it into electrical energy has increased with the development of new materials and techniques. This has sparked interest in the engineering community to establish more and more applications that utilize energy harvesting technologies for power generation.

Some of the energy harvesting systems which use different sources to generate electrical energy and their efficiencies are given below; [1]

- mechanical energy into electricity-generators (20-70\% efficiency), piezoelectric systems (0,5-15\% efficiency)

- chemical into electricity; fuel cells (25-35\% efficiency), primary batteries, rechargeable batteries

- heat/cold into electricity; seebeck-elements (2-5\% efficiency)

- electromagnetic radiation into electricity; photovoltaic systems.

Piezoelectric effect is a unique property that allows materials to convert mechanical energy to electrical energy and conversely, electrical energy to mechanical energy. The stimuli for piezoelectric materials can be human walking, wind, rain, tide and wave etc. This effect can be an inherent property of the material or it can be imparted to an existing non-piezoelectric material. However, not every material can be made piezoelectric, only certain ceramics and polymers have the ability to become piezoelectric. Therefore, the chapter will contain fundamentals of piezoelectric effect, a historical review on piezoelectric energy harvesting 
and recent developments such as flexible piezoelectric fibres which can be integrated or embedded into flexible structures.

Since the sun is the most abundant renewable energy source in the world and the solar energy the earth receives in an hour is greater than the energy consumed in a year. This makes the photovoltaic (solar) materials one of the most significant alternative energy harvesters. This chapter will contain the statistics for solar cell production in EU countries between 2000 and 2010 and also the electricity generated by photovoltaic cells in Europe in 2010 will also be highlighted. The fundamentals of photovoltaic materials and different cell types such as organic, inorganic, dye-sensitized and tandem will be reviewed in this chapter. The chapter will also contain an historical review on the photovoltaic energy harvesters, their efficiencies and the most recent developments are included.

\section{Piezoelectric energy harvesting}

One of the most widely used smart materials is piezoelectric materials because of their wide band width, fast electro mechanical response, relatively low power requirements and high generative forces. Figure 1 presents a market review on piezoelectric materials corresponding to their applications and market share (\%) in 2007.

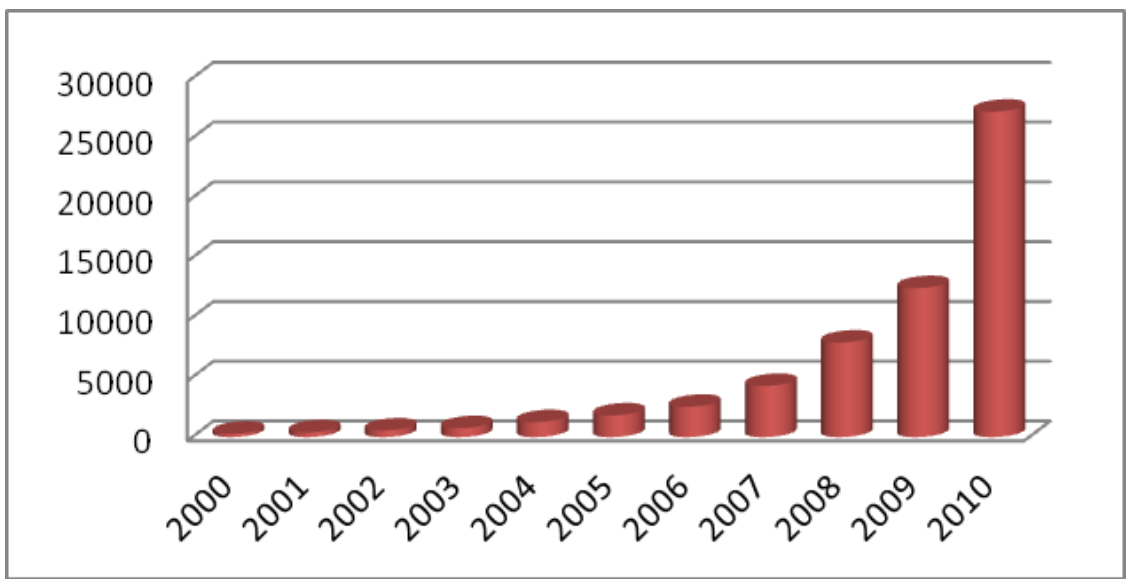

Figure 1. Piezoelectric devices market share overview on applications [2]

As it can be seen in Figure 1, information technology/robots is the leader of the market with $31.7 \%$ global market share while acoustic devices and resonators have the lowest share in the market with $3.1 \%$. The others in the global market between these two applications can be given from high market share to low; semiconductor manufacturing and precision machines $(18.6 \%)$, sonar $(12.5 \%)$, bio/medical $(11.1 \%)$, ecology and energy harvesting $(7 \%)$, accelerators and sensors (5.8\%), non-destructive testing $(5.7 \%)$ and miscellaneous which includes gas igniters, piezo printing heads and telecommunication devices (4.5\%). It has been reported by Innovative Research and Products (iRAP) Inc. that the global market for 
piezoelectric devices equals to US $\$ 10.6$ billion and a high growth is expected over a 5-year period and to reach a value of US\$19.5 billion by 2012 .

Energy harvesting applications for piezoelectric devices is less than $10 \%$ however it can change dramatically if the importance of piezoelectric materials is recognised for alternative energy from nature with zero carbon foot print.

Piezoelectric behaviour was first found in some crystals. According to historical reviews on piezoelectricity [3-4] Charles Coloumb was the first person who theorized in 1817 that electricity may be produced by the application of pressure to certain types of materials. However, it was only a notion until the actual discovery of the "direct-piezoelectric phenomenon" on quartz by Pierre and Jacque Curie [5]. They placed weights on the crystals and detected some charges on the surface and also observed that the magnitude of detected charge was proportional to the applied weight.

Lippmann [6] predicted that if a material could generate electrical charge when a is pressure applied, the reverse effect may be possible so that a mechanical strain could be developed when an electrical charge is applied and this notion was then supported by Curie brothers' experimental results [7]. These two domains had been known as "direct pressure-electric effect" and "converse pressure-electric effect" until Hankel [3] suggested the name "piezoelectricity". Piezoelectricity comes from the Greek words "piezo" and "electricity" that the word "piezo" is a derivative of a Greek word which means "to press" and "electricity" has the same meaning as English word "electricity".

Piezoelectric effect exists in two domains; namely, direct piezoelectric effect and converse piezoelectric effect. Direct piezoelectric effect describes the ability to convert mechanical energy to electrical energy which is also known as generator or transducer effect while the converse piezoelectric effect describes the ability of transforming electrical energy to mechanical energy which is also known as motor/actuator effect. The electrical energy generated by direct piezoelectric effect can be stored to power electronic devices and it is known as "energy/power harvesting".

Piezoelectric materials are member of ferroelectrics so that the molecular structure is oriented such that the material exhibits a local charge separation, known as electric dipole. Electric dipoles in the artificial piezoelectric materials composition are randomly oriented, so the material does not exhibit the piezoelectric effect. However, the electric dipoles reorient themselves when a strong electrical field is applied as shown in Figure 2.

The orientation is dependent on the applied electrical field which is known as poling. Once the electric field is extinguished, the dipoles maintain their orientation and the material then exhibit the piezoelectric effect so that an electrical voltage can be recovered along any surface of the material when the material is subjected to a mechanical stress [8]. However, the alignment of the dipole moments may not be perfectly straight because each domain may have several allowed directions. The piezoelectric property gained is stable unless the material is heated to or above its Curie temperature $\left(\mathrm{T}_{\mathrm{c}}\right)$. However, it can be cancelled by the application of an electric field that is opposite to the direction of the material. 


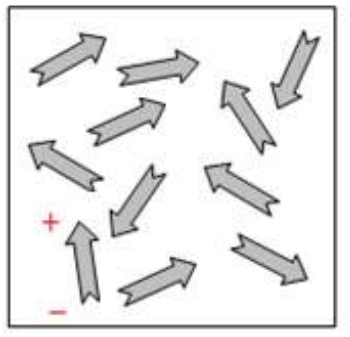

(a)

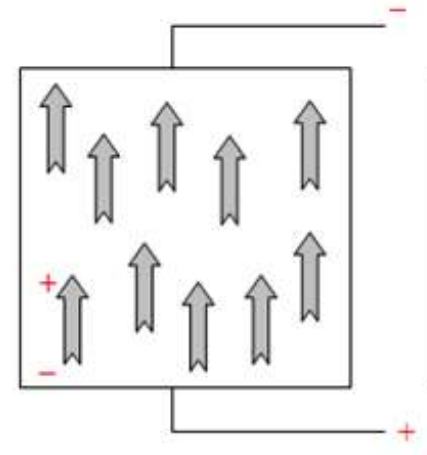

(b)

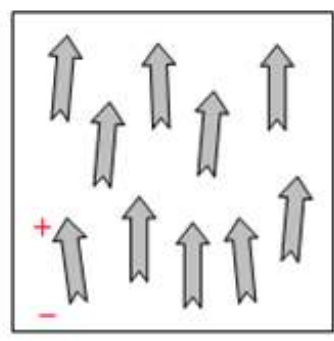

(c)

Figure 2. Orientation of dipoles by polarization, (a) random orientation of polar domains, (b) application of high DC electric field (polarization), (c) remnant polarization after the electric field is extinguished.

According to the definition of "direct piezoelectric effect", when a mechanical strain is applied to crystals by an external stress, an electric charge occurs on the surface(s) of the crystal and the polarity of this observed electric charge on the surface(s) can be reversed by reversing the direction of the mechanical strain applied as shown in Figure 3.

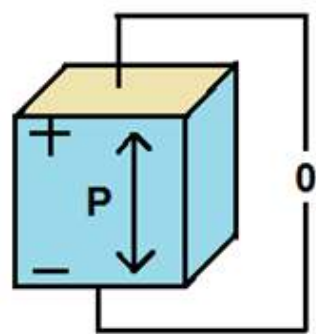

(a)

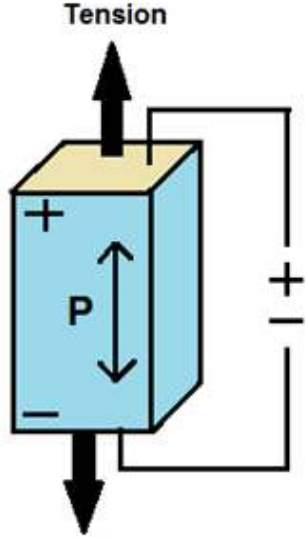

(b)

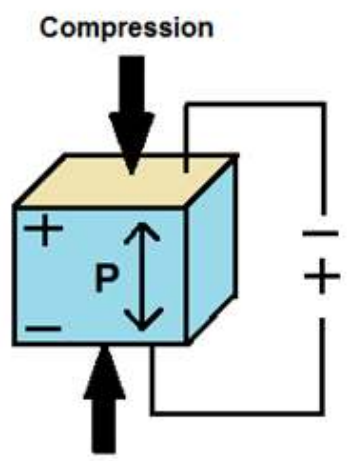

(c)

Figure 3. Schematic of direct piezoelectric effect; (a) piezoelectric material, (b) energy generation under tension, (c) energy generation under compression

On the other hand, according to the definition of "converse piezoelectric effect", when an electric field is applied to a crystal or a crystal is subjected to an electric field, a mechanical deformation on the surface is observed which is generally seen as a change in dimensions of the crystal. The direction of the mechanical strain can also be reversed as shown in Figure 4, by reversing the applied electric field. 


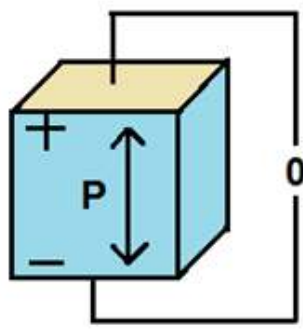

(a)

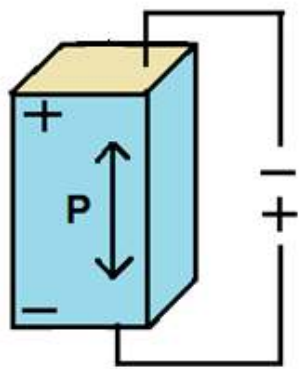

(b)

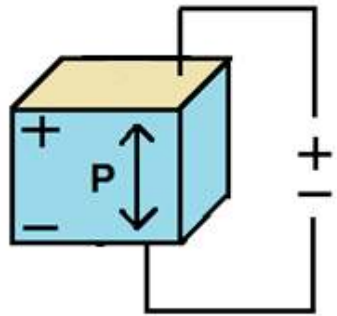

(c)

Figure 4. Schematic of converse piezoelectric effect; (a) piezoelectric material, (b) dimensional change when an electrical charge applied, (c) dimensional change when an opposite electrical charge applied.

Piezoelectricity can be seen in different structures;

- Naturally occurring biological piezoelectric materials

- Wood [9-10]

- $\quad$ Bone and tendon [11-12]

- Keratin, silk [13-14]

- Enamel [15]

- Myosin [16]

- $\quad$ Deoxyribonucleic acid (DNA) [17]

- $\quad$ Ribonucleic acid (RNA) [18]

- Naturally occurring piezoelectric crystals

- Quartz [5]

- Rachell salt

- Tourmaline

- Man made piezoelectric ceramics

- $\quad$ Barium titanate - $\mathrm{BaTiO}_{3}[19]$

- $\quad$ Lead titanate $-\mathrm{PbTiO}_{3}[20]$

- $\quad$ Lead zirconate titanate $-\mathrm{Pb}(\mathrm{Zr}, \mathrm{Ti}) \mathrm{O}_{3}-\mathrm{PZT}$ [21-23]

- $\quad$ Potasium niobate $-\mathrm{KnbO}_{3}[24]$

- $\quad$ Lithium niobate - $\mathrm{LiNbO}_{3}$ [25-26]

- $\quad$ Lithium tantanate - $\mathrm{LiTaO}_{3}[26]$

- Man made piezoelectric polymers

- $\quad$ Polyvinylidene fluoride - PVDF [27]

- Polyparaxylene

- poly-bischloromethyuloxetane

- Aromatic polyamides

- Polysulfone

- Polyvinyl fluoride

- Synthetic polypeptide 
Polymeric materials can be produced as large thin sheets and then can be cut or stamped into nearly any shape. They also exhibit high mechanical strength and high impact resistance when compared to ceramic materials. Although the piezoelectric charge constant of polymers are lower than that of ceramics, they have much higher piezoelectric voltage constant than that of ceramics which indicates better sensing characteristic.

Polymers consist of two regions; crystalline and amorphous. The percentage of crystalline region in a polymer matrix determines the piezoelectric effect. However, crystallites are dispersed in amorphous region in semi-crystalline polymers as shown in Figure 5.

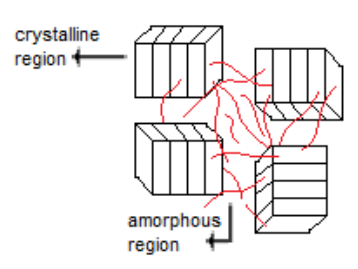

(a) melt cast

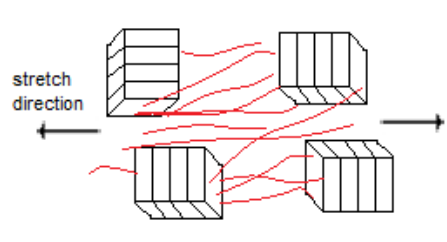

(b) mechanically oriented

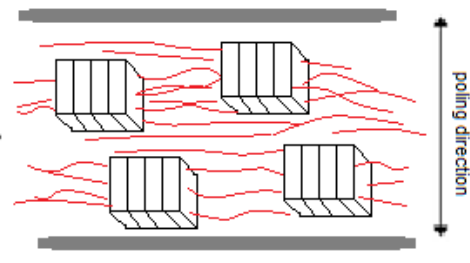

(c) electrically poled

Figure 5. Amorphous and crystalline regions in the polymer matrix; from melt cast (a), during mechanical orientation (b) and electrically poling (c) [28]

The melting temperature of a polymer is dependent on the percentage of crystalline region in the polymer while the amorphous region designates the glass transition temperature and mechanical properties of the polymer. As it is seen in Figure 5 crystalline structures and so the molecular dipoles are locked in the amorphous region. Broadhurst et al. [29] studied the molecular and morphological structure of PVDF and its pyroelectric and piezoelectric properties. If a DC voltage is applied across the polymeric piezoelectric material, the material becomes thinner, longer and wider in proportion to the voltage, conversely the film generates a proportional voltage when a mechanical stress is applied either by compression or stretching. The relationship between applied mechanical stress and generated voltage can be defined by stress constants.

\subsection{Comparing piezoelectric materials}

As it can be seen from the Table 1 the piezoelectric constant is lower for polymers as compared to ceramic based piezoelectric materials. Therefore, when the same amount of voltage applied to polymer and ceramic piezoelectric materials, the shape change of ceramic based materials are larger than polymers. Although PVDF has a lower piezoelectric charge coefficient, its piezoelectric voltage coefficient is about 21 times higher than that of PZT and 40 times higher than that of $\mathrm{BaTiO}_{3}$, therefore PVDF is better for sensor applications. Due to being a polymer, PVDF is flexible, light weight, tough, readily manufactured into large areas and can be cut and formed into complex shapes.

The electromechanical coupling constants $\left(\mathrm{k}_{31}\right)$ of PZT is approximately 2.5 times larger than the electromechanical constant of PVDF which means it is able to convert 2.5 times more mechanical stress into electrical energy than that PVDF. 


\begin{tabular}{|l|l|c|c|c|}
\hline Property & Units & BaTiO $_{3}$ & PZT & PVDF \\
\hline Density & $10^{3} \mathrm{~kg} / \mathrm{m}^{3}$ & 5.7 & 7.5 & 1.78 \\
\hline Relative permittivity & $\varepsilon / \varepsilon_{0}$ & 1,700 & 1,200 & 12 \\
\hline Piezoelectric strain coefficient $\left(\boldsymbol{d}_{31}\right)$ & $10^{-12} \mathrm{C} / \mathrm{N}$ & 78 & 110 & 23 \\
\hline Piezoelectric voltage coefficient $\left(\boldsymbol{g}_{31}\right)$ & $10^{-3} \mathrm{Vm} / \mathrm{N}$ & 5 & 10 & 216 \\
\hline Pyroelectric voltage coefficient $\left(\boldsymbol{P}_{\boldsymbol{v}}\right)$ & $\mathrm{V} / \mu \mathrm{m} \mathrm{K}$ & 0.05 & 0.03 & 0.47 \\
\hline $\begin{array}{l}\text { Electromechanical coupling constant } \\
\left(\boldsymbol{k}_{31}\right)\end{array}$ & $\% @ 1 \mathrm{kHz}$ & 21 & 30 & 12 \\
\hline Acoustic Impedance & $\left(10^{6}\right) \mathrm{kg} / \mathrm{m}^{2}-\mathrm{sec}$ & 30 & 30 & 2.7 \\
\hline
\end{tabular}

Table 1. Typical properties of commercially available 3 main piezoelectric materials [30]

\subsection{History and recent developments on piezoelectric energy harvesting}

One of the very early studies of energy harvesting by piezoelectric materials was performed in a biological environment by Hausler and Stein [31]. They claimed that a piezoelectric PVDF film and a converter could transform the mechanical energy caused by respiration of a mongrel dog to electrical energy. The piezoelectric material was fixed to the ribs of the dog and a peak voltage of $18 \mathrm{~V}$ was produced by motions of the ribs during the spontaneous breathing. However, the power generated was about $17 \mu \mathrm{W}$ which was not enough to operate an electronic device.

More than a decade after the study on animals, Starner [32] studied the possibility of energy harvesting from body motions by using piezoelectric materials. He claimed that a human body could be a source for harvestable electric energy. Starner studied different part of the body, such as walking, upper limb motion, finger movements, blood pressure etc., and analysed the possibility of harvestable power from these locations. He claimed that the amount of power lost during walking was about $67 \mathrm{~W}$ and by mounting a PZT device inside a shoe with an efficiency of $12.5 \%$, up to $8.4 \mathrm{~W}$ electrical energy could be generated. He also, suggested the possibility of storing the harvested energy by using a capacitor.

Parasitic energy harvesting from walking of a human being to power a radio frequency identification transmitter was studied by Kymissis et al. [33]. They used three different devices which were a thunder actuator consisting of a ceramic based piezoelectric composite material, a rotary magnetic generator and a PVDF stave. Former two structures were integrated into the heel of a shoe to harvest the impact energy while the PVDF stave was integrated into the sole to absorb the bending energy. The researchers constructed a prototype to investigate and compare the energy generation performance of these three different materials. The peak power generated by PZT unimorph structure was 4 times higher than PVDF stave, $80 \mathrm{~mW}$ and $20 \mathrm{~mW}$ respectively. However, the peak power generated by the rotary generator was found to be only $0.25 \mathrm{~mW}$ which was found not to be sufficient to power a radio frequency identification transmitter. 
Shenck [34] demonstrated the harvestable power generation from a rigid bimorph piezoceramic transducer, which was integrated into the sole of a shoe. Different regulation systems were evaluated. One of the findings was that the use of a second piezoelectric material leads to more energy generation. Furthermore, it was found that a bimorph transducer was more effective for the application since it was better adapted to various distributions of body weight and footfall velocity. Shenck and Paradiso [35] also studied piezoelectric PVDF and PZT structures embedded in a shoe. A power storage circuit which was designed to power a radio frequency tag was also mounted in a shoe and an offline forward switching DC-DC converter was developed. The experimental results showed that the switching converter harvested energy more efficiently -about twice as much- than the original linear regulator circuit. The whole set-up was successful to power low energy electronic devices since the switching circuit provided continuous power during walking.

Churchill et al. [36] investigated the power harvesting capability of a piezoelectric fibre composite structure consisting of unidirectionally aligned PZT fibres of $250 \mu \mathrm{m}$ diameter embedded in a resin matrix. It was found that $7.5 \mathrm{~mW}$ of power could be harvested from a piezoelectric fibre composite material - with a length of $130 \mathrm{~mm}$, a width of $13 \mathrm{~mm}$ and a thickness of $0.38 \mathrm{~mm}$ - when a vibration of $180 \mathrm{~Hz}$ was applied. In another work the possibility of power harvesting was performed by Renaud et al. [37].They studied the wrist and arm motions during walking. They found that a spring mass resonant system was not appropriate for energy harvesting from arm since motions caused by arm movements were low in frequency. An analytic model for a non-resonant system was developed and it showed that a maximum power of $40 \mu \mathrm{W}$ could be generated from the wrist movements during walking.

Granstrom et al. [38] developed a theoretical model of an energy harvesting backpack that can generate electrical energy from flexible piezoelectric PVDF films integrated into the straps. It was found that $45.6 \mathrm{~mW}$ of power could be generated from a complete backpack with two piezoelectric straps with an efficiency of more than $13 \%$. Swallow et al. [39] developed a micropower generator using micro composite based piezoelectric materials for energy reclamation in glove structures. They developed fibre composite structures by using different fibre diameters embedded between two copper electrodes and both the effect of fibre diameter and the materials thickness were investigated. Their results showed that the composite structure was able to produce a voltage up to 6 volts. Siores and Swallow [40] developed an apparatus for detection and suspension of muscle tremors.

A multi-material piezoelectric fibre production has been reported by Egusa et al. [41] however it was produced by a multi-process method where a copolymer of PVDF, P(VDFTrFE) and polycarbonates were used, which makes the fibre expensive and difficult to scale up for production. The first flexible piezoelectric fibre has been produced successfully by Siores et al. [42] via a continuous process on a customised melt extruder. This is a cost effective process since the polarisation of the fibre is carried out during the fibre production and the process is easy to scale up for production. 


\section{Photovoltaic effect and photovoltaic energy harvesting}

The sun is the most abundant renewable energy source in the World. The solar energy which the Earth receives in an hour is greater than the energy consumed in a year. If we need to present the situation by numbers, the received solar power is about 120,000 Terawatts while the global energy consumption is about 13 Terawatts [43].

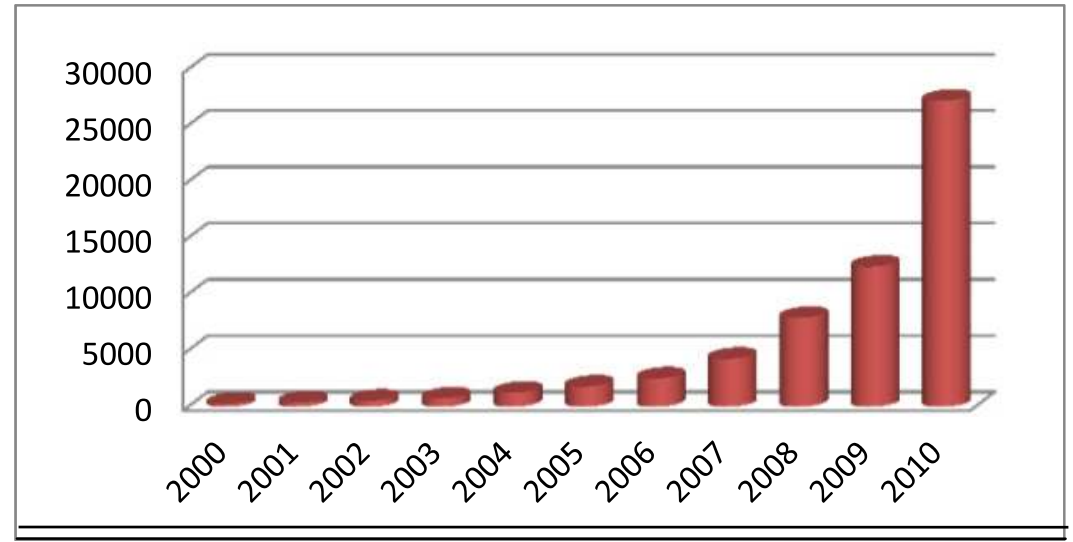

Figure 6. Number of solar cell production between 2000 and 2010 in European Countries [44]

The importance of renewable energy generation increases significantly with an increase in global warming, air and water pollution etc. The most of the European countries have started using PV cells for their electrical energy need. Figure 6 clearly shows the dramatic increase in the PV cell production in Europe over a 10-year period. Increasing demand on the solar cell production has shown a steady increase since 2000. This may be a result of the increased awareness of global warming and the need for using environmentally friendly materials and techniques. The number of solar cell production in EU countries was more than doubled in a year between 2009 and 2010.

Figure 7 shows the projected solar power generation in European countries. It is clear that the largest solar power generator is Germany followed by Italy, Czech Republic and France. Although Spain is known as a sunny country, the production of power from solar cells is almost 20 times less than that of Germany. Mostly dull and cloudy countries like Latvia and Estonia pointed as "Rest of the EU" in the figure and United Kingdom have much lower solar power generation and their portion is under $1 \%$.

Photovoltaic effect was first observed by Alexandre-Edmond Becquerel in 1839 when he subjected an $\mathrm{AgCl}$ electrode in an electrolyte solution to the light. The word "photo" is a Greek word used for light and "voltaic" named after Alessandro Volta. The beam of sunlight contains photons which may contain different amount of energy related to the different wavelengths of the solar spectrum. When a photovoltaic material is exposed to sunlight, photons may be reflected, absorbed or transmitted. Only the absorbed photons with energy greater than the bandgap energy can generate electricity by causing the 
breakage of covalent bonds and dislodging of the electrons from the atoms of the cell. The free electrons start moving through the cell and during this movement they create and fill in the cell's vacancies to generate electricity. The ability of materials to absorb photons and convert into electricity is known as photovoltaic effect [46-47]. Two fundamental processes of PV effect, light absorption and charge separation, are the basis of all inorganic PV cells.

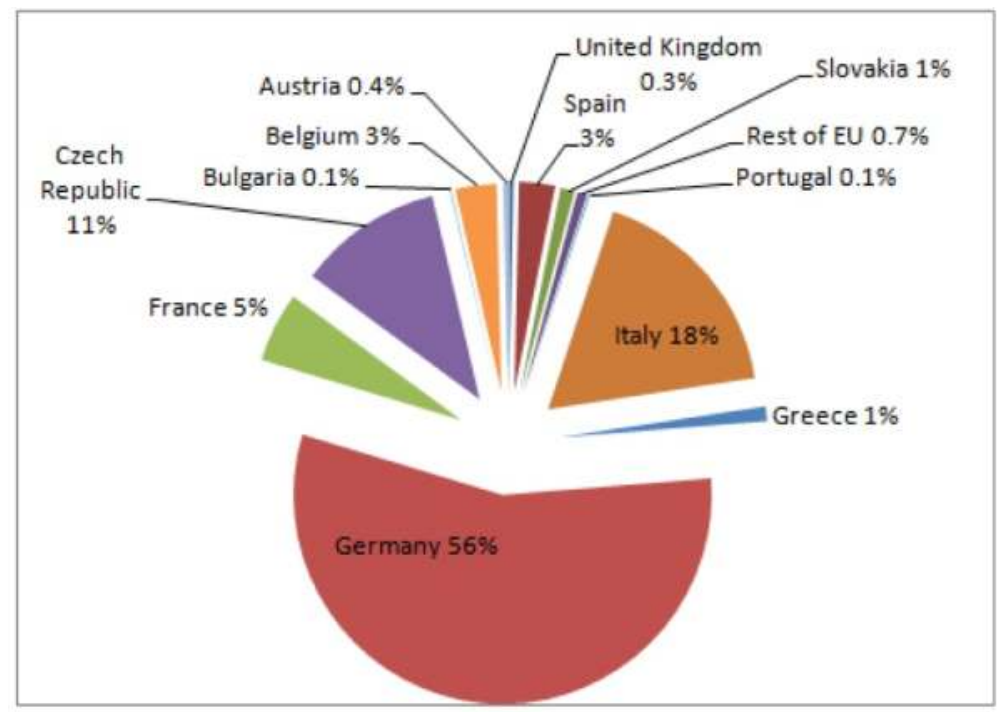

Figure 7. PV market share (MW, \%) in EU in 2010 and evaluation until 2015 [45]

The proportion of sunlight energy is significant for the conversion efficiency of a PV cell which converts sunlight energy to electrical energy. The efficiency of PV energy is important to make PV energy competitive with more traditional sources of energy, such as fossil fuels. For comparison, the earliest PV devices converted about $1 \%-2 \%$ of sunlight energy into electric energy. Today, it is likely to produce photovoltaic structures made of pure silicon with $24.7 \%$ efficiency [48-49] however, due to the rigidity of silicon based solar cells and pursuit of light weight and flexible photovoltaic materials for curved structures, applications are limited. Photovoltaic materials based on conjugated polymers, due to ease of processing, low-cost fabrication, being light weight and flexible, are evolving into a promising alternative to silicon based solar cells [50-51].

\subsection{Inorganic photovoltaic materials}

The best example for inorganic photovoltaic material is silicon. It is the most commonly used material which absorbs light and creates electron-hole pairs. The individual inorganic solar cells are designed with a positive (p-junction) and a negative (n-junction) layer to create an electric field. When n-type layer is doped, the element with an extra electron, generally phosphorous, is used to give a negative charge to the layer. On the other hand, when p-type layer is doped, the element with a less electron, generally boron, is used to give 
a positive charge to the layer. The place in between these two layers is called p-n cell junction.

Electrons in n-type layer are free and travel through the material to lower energy levels while holes travel to higher energy levels when the photovoltaic cell is exposed to the sunlight. Free electrons jump across the p-n cell junction. These electrons then return to the n-type layer when the two sides of the cell are connected with a wire and this electron flow is known as "the electric current". The Figure 8 clearly presents the layers of an inorganic PV cell and the generation of electric current by flowing electrons.

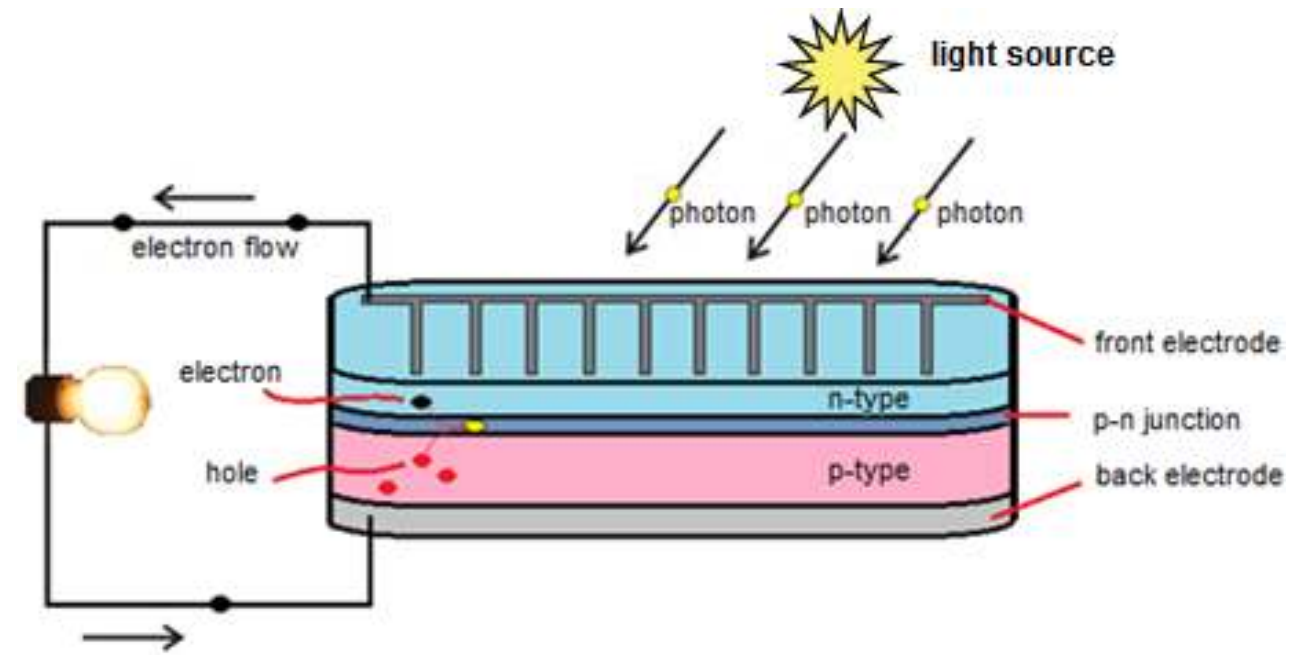

Figure 8. Layers and working principle of a silicon solar cell

Crystalline, multi-crystalline, amorphous and microcrystalline silicon, copper indium gallium diselenide (CIGS), the III-V compounds and alloys, CdTe, InP, Cu2Se, WSe2, GaAs etc. are mostly used as inorganic semiconductor materials for PV cells [52-53]. These semiconductor materials, used for inorganic PV cell fabrication, have energy bandgaps within the range of 1.1-1.7 eV which make them desirable due to being near to the optimum energy bandgap of $1.5 \mathrm{eV}$ for PV energy conversion by a single junction solar cell [54]. Many researchers have concentrated on increasing the efficiency and achieving maximum power. Recorded efficiency for a free-standing $50 \mu \mathrm{m}$ thin film monocrystalline silicon solar cell is $17 \%$ [55], for $47 \mu \mathrm{m}$ thin film silicon cell is $21.5 \%$ [56] and maximum recorded efficiency for inorganic solar cells is $24.7 \%$ [57].

\subsection{Organic photovoltaic materials}

Semiconducting polymers with suitable bandgaps, absorption characteristics and physical properties can be used for the fabrication of organic photovoltaic materials. They are cheaper raw materials as compared to silicon based inorganic solar cells and they can also be fabricated by using cheap processing techniques. Photovoltaic effect of organic PV cells is 
based on electron transfer from donor-type semiconducting conjugated polymers to acceptor-type conjugated polymers or acceptor molecules, such as fullerenes [58]. These materials have donor-acceptor heterojunctions to achieve separation of the electron-hole pairs. Most of the semiconducting polymers are hole-conductors and known as electron donor polymers.

There are six basic operational principles for a polymer solar cell [59-60] as listed below:

1. Coupling of the photons

2. Photon absorption by active layer, $\eta_{\text {abs, }}$

3. Electron-hole pair creation (excited state) and diffusion, $\eta_{\text {diff, }}$

4. Charge separation, $\eta_{\mathrm{tc}}$,

5. Charge transportation within the respective polymer to the respective electrodes, $\eta_{\text {tr, }}$

6. Charge collection, $\eta_{\mathrm{cc}}$

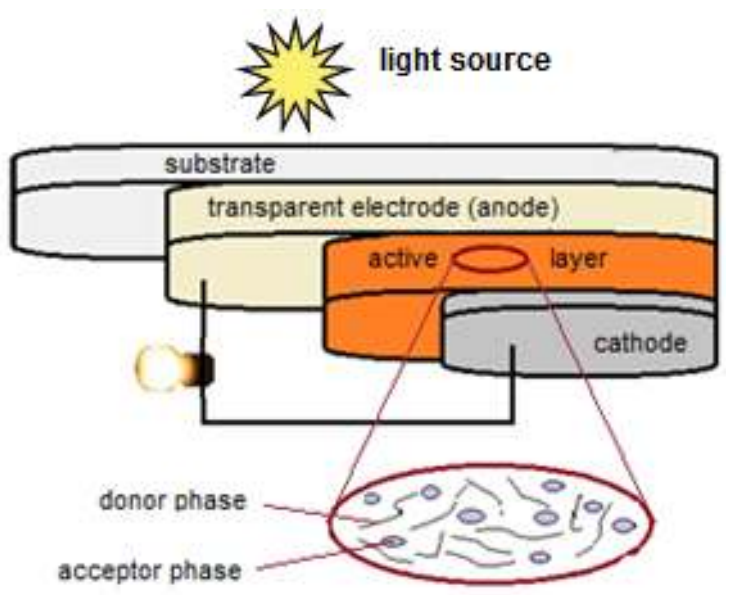

Figure 9. Donor-acceptor heterojunction configurations in a typical organic solar cell

When the photoconductive properties of organic polymers was first observed, the most widely studied polymer was poly(vinyl carbazole), PVK [61]. Other suitable electron donor polymers for organic photovoltaics include;

- $\quad$ poly(3-hexylthiophene), P3HT,

- $\quad$ po5ly(3-octylthiophene), (Р3OT)

- polyphenylenevinylene, (PPV)

- $\quad$ polyfluorene, (PFO)

- poly[2,7-(9,9-dioctyl-fluorene)-alt-5,5-(4,7'-di-2-thienyl-2', $1^{\prime}, 3^{\prime}$, -benzothiadiazole), (PFODBT)

- $\quad$ poly[2-methoxy-5-(2'-ethyl-hexyloxy)-1,4-phenylene vinylene], (MEH-PPV)

- poly[2-methoxy-5-(3,7-dimethyloxy)]-1,4-phenylenevinylene), (MDMO-PPV)

- $\quad$ poly[N-9'-hepta-decanyl-2,7-carbazole-alt-5,5-(4',7'-di-thienyl-2', $1^{\prime}, 3^{\prime}$-benzothiadiazole, (PCDTBT) 
Semiconducting polymers have lower dielectric constant but higher extinction constant than that of inorganic PV materials. To absorb the most incident light about 300nm thickness is enough for a film material [62]. However, the optimized thickness for most polymer solar cells is less than 100nm [63] due to the low carrier mobility.

Electron acceptors with high electron mobility are the most suitable materials for polymer solar cells. Due to exhibiting $1 \mathrm{~cm}^{2} \mathrm{~V}^{-1} \mathrm{~s}^{-1}$ electron mobility [64], ultrafast photo induced charge transfer and derivatives of $\mathrm{C}_{60}$ and $\mathrm{C}_{70}$ are the best electron acceptors so far. Suitable electron acceptor polymers for organic photovoltaics include;

- 6,6-phenyl-C61-butric acid methyl ester, (PC60BM)

- 6,6-phenyl-C71-butric acid methyl ester, (PC70BM)

- $\quad \operatorname{poly}\left(9,9^{\prime}\right.$-dioctylfluorene-co-bis-N,N'-(4-butylphenyl)-bis-N, $\mathrm{N}^{\prime}$-phenyl-1,4phenylenediamine, (F8TB)

- $\quad$ poly-[2-methoxy-5,2'-ethylhexyloxy]-1,4-(1-cyanovinylene)-phenylene,(CN-MEH-PPV)

\subsection{Dye-sensitized photovoltaic materials}

The dye-sensitized solar cells (DSSC or DSC) are thin film photovoltaic materials. They are also known as "the 3rd generation solar cells". The first DSSCs were studied by Gerischer et al in late 1960s who illustrated that organic dyes can generate electricity at oxide electrodes in electrochemical cells [65]. The first actual work on DSSCs was carried out with a chlorophyll sensitized zinc oxide $(\mathrm{ZnO})$ electrode. In this work, photons were converted into an electric current by charge injection of excited dye molecules into a wide bandgap semiconductor for the first time [66]. DSSCs have slightly different working principle than traditional silicon solar cells. Light absorption and charge carrier transport processes are separated in DSSCs. Light is absorbed by a sensitizer, which is affixed to the surface of a wide band semiconductor. Charge separation takes place at the surface via photo-induced electron injection between dye, semiconductor and electrolyte [67-68].

When a DSSC is exposed to the sun light, photons pass through the transparent electrode into the dye (active) layer and excite electrons. Excited electrons move toward the transparent electrode where they are collected. Once an electron completes its travel through the external circuit, it is re-induced into the DSSC on the back electrode and flows into the electrolyte and then it is transported back to the dye molecules [69].

After the discovery of DSSCs in late 1960s and early 1970s, DSSCs have attracted many researchers' attention and a significant number of works have been carried out on suitable transparent electrodes [70-71], and electrolytes [72] but mostly on increasing the efficiency of DSSCs [73-78].

DSSCs have some advantages over inorganic solar cells as given below:

- low cost materials,

- the electron is injected from a dye into $\mathrm{TiO}_{2}$, there is no electron-hole pair,

- DSSCs can work even in low density light conditions which make them possible to be used for some indoor applications, 
- $\quad$ DSSCs can operate at lower internal temperatures even in a hot environment.

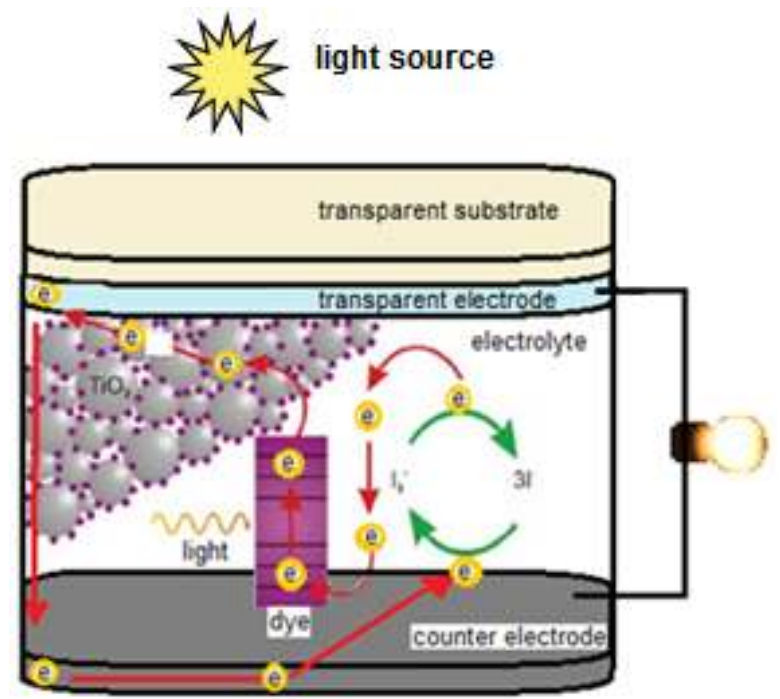

Figure 10. Dye-sensitized solar sell structure; transparent electrode coated transparent substrate and over it a $\mathrm{TiO}_{2}$ layer sensitized by a monolayer of adsorbed dye (photo-electrode), electrolyte and counter electrode.

On the other hand, the power conversion efficiency of DSSCs is lower than silicon based inorganic solar cells. There is also a possibility of breakdown of the dye material and leakage of liquid electrolyte.

\subsection{Tandem cell photovoltaic materials}

Tandem solar cells (TSCs) are developed to overcome some drawbacks of conventional solar cells. Each active material used to fabricate a solar cell can only convert certain wavelength of the light to electricity. To achieve better photon absorption efficiency, two or more active materials with different bandgaps are linked to built-up a TSC. Two or more heterojunction solar cells are deposited on top of each other to create a TSC. One of the photo-active materials with a higher bandgap collects photons with higher energy while the other with a lower bandgap absorbs photons with lower energy (Figure 11).

Since solar cells with different bandgaps are used, when the structure is built-up, semiconductor material with a wide band gap is used as the first active layer and semiconductor material with a smaller band gap is used as the second active layer. When the individual cells are connected in series to create a TSC, the open-circuit voltage ( $\mathrm{V}_{\text {oc }}$ ) of tandem cell is increased to the sum of the $\mathrm{V}_{\text {oc }}$ of individual cells [79]. The maximum efficiency calculated for a tandem solar cell consisting of 2 sub-cells is $42 \%$ with band gaps of 1.9 and $1.0 \mathrm{eV}$ and calculated maximum efficiency for a tandem solar cell consisting of 3 sub-cells is $49 \%$ with band gaps of 2.3, 1.4 and $0.8 \mathrm{eV}$ [80]. However, experimental studies on 
tandem solar cells consisting of GaInP/GaInAs/GaInAs showed only an efficiency of $33.8 \%$ [81] and 38.9\% [82]. The maximum efficiency calculated for organic tandem solar cells consisting of 2 sub cells is close to $14 \%$ [83].

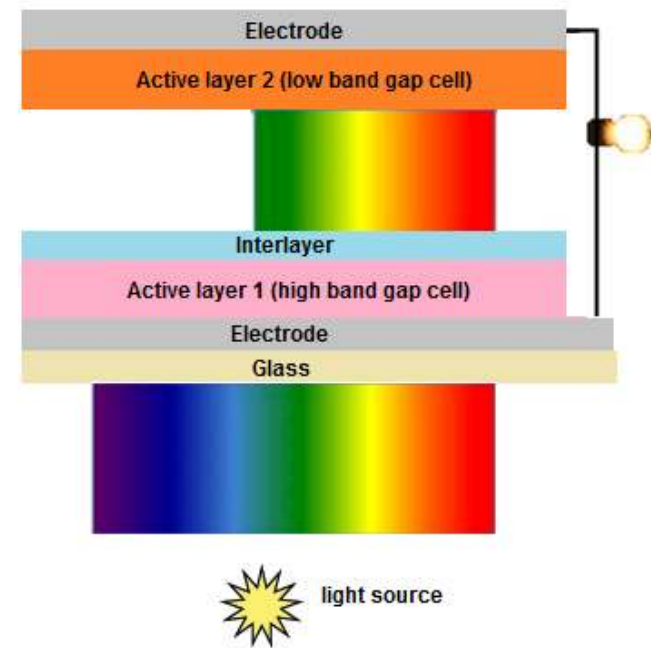

Figure 11. Tandem solar cell structure consisting of two photovoltaic cells having different band gaps

\subsection{Hybrid photovoltaic materials}

To combine the unique properties of inorganic semiconductor nanoparticles with organic polymeric materials, both organic and inorganic nanostructures are combined and named as "hybrid solar cell" (HSC). Organic materials absorb light as a donor and transport holes while inorganic materials act as an acceptor to transport electrons. The combination of organic and inorganic photoactive materials provides some advantages over individual organic and inorganic solar cells. The overall cost of the solar material is reduced by using organic thin film technology which is low cost, easy to manufacture and versatile while inorganic nanoparticles add high absorption coefficient and bandgap tenability [84].

The idea of making hybrid solar cells has attracted many researchers who then worked on different concepts of HSC manufacturing by using bulk heterojunction concept with different nanoparticles such as $\mathrm{TiO}_{2}$ [85], PbS [86-87], ZnO [88-89], CdS [90], CdSe [91-92], CdTe [93] and CuInS2 [94]. Although HSCs provide some advantages over inorganic solar cells, such as low cost, reduced thickness (being thin film), easy manufacturing, versatility, tuneable nanoparticle size thus tuneable bandgap etc., the power conversion efficiency of HSCs is still lower than that of silicon based inorganic solar cells.

\subsection{Brief history and recent developments on photovoltaic energy harvesting}

Since the discovery of photovoltaic effect by Becquerel, researchers have studied and worked on various photoactive materials and methods of making photovoltaic cells. The 
first solar cell was developed at Bell Laboratories [95], which was silicon based inorganic solar cell with power conversion efficiency of $6 \%$. The highest reported power conversion efficiency for inorganic solar cells today is $24.7 \%$ [96].

Polymers including poly(sulphur nitride) and polyacetylene were investigated for their photoelectric property in the 1980s. Using a donor and an acceptor material in a cell was a real breakthrough for organic photovoltaics. A donor - acceptor cell may consist of dye dye, polymer - dye, polymer - polymer or polymer - fullerene blends [97]. Due to having high electron affinity, fullerenes have become the most widely used acceptor materials in organic solar cells and thus polymer - fullerene blends have received a particular interest from researchers. Photophysics of various conjugated polymer/ $\mathrm{C}_{60}$ blends have been extensively studied and reported [98-104].

MEH-PPV:C60 and MDMO-PPV:PCBM were the most predominant active layer materials. However, due to exhibiting large bandgap and low mobility of the PPV type polymers, efficiencies are limited to 3\% [105-108]. Therefore, researchers have started to work on different polymers and $\mathrm{P} 3 \mathrm{HT}$ has become the most predominant active layer material for OPVs and also its blends with PCBM.

Probably, the starting point of the rapid developments on P3HT:PCBM based OPVs was the work published in 2002 [109]. These researchers investigated the short-circuit current density of P3HT:PCBM based organic solar cells with a weight ratio of 1:3 in active layer. They also recorded that it was the largest short-circuit current density $\left(8.7 \mathrm{mAcm}^{-2}\right)$ observed in OPVs at that time.

A number of studies have been carried out to increase the efficiency of P3HT:PCBM cells by thermal annealing [109-116]. It was found that the Voc was usually slightly decreased after annealing process while both the Isc and FF increased significantly [117] and provides optimum charge carrier creation and extraction.

The morphology and the optimization of the weight ratios for donor and acceptor are also important for a desirable performance. Studies showed that morphology of P3HT and PCBM can be modified upon [118-120]. Padinger et al. [121] applied a post-treatment to P3HT:PCBM based solar cell by annealing and applying an external voltage greater than the open-circuit voltage, simultaneously. They reported that the post treatment increased all the parameters, such as $\mathrm{I}_{\mathrm{sc}}, \mathrm{V}_{\mathrm{oc}}$ and $\mathrm{FF}$, thus the overall efficiency reached $3.5 \%$ from $0.4 \%$ (without any post treatment).

There have been other approaches to control the morphology of P3HT:PCBM blends. It has been reported by Li et al. [122] that controlling the morphology of P3HT and PCBM in the blend is possible by slow drying. It has also been reported that additives, such as nhexylthiol, n-octylthiol, or n-dodecylthiol [123], can also contribute to the hole mobility enhancement slightly and charge-carrier lifetime significantly. Another approach to control the morphology was addition of nitrobenzene to P3HT:PCBM solution (in chlorobenzene) that increased the efficiency as high as $4 \%$ without thermal annealing [124-125]. 
The effect of weight ratio of P3HT and PCBM on the power conversion efficiency of OPVs has been extensively studied. Reports from various researchers confirmed each other's work and the optimum weight ratio is considered as 1:1 [122, 126-129]. Table 2-4 shows the improvements in the efficiencies of P3HT:PCBM based organic photovoltaic materials.

One of the most recent approaches is based on the growth of fibres by slow cooling of P3HT solutions [124]. The crystalline fibres are isolated from the amorphous material by centrifugation and filtration and then reformulated in dispersions with PCBM.

The highest PCE reported recently is just than 6\% for OPV [130]. Researchers used a copolymer, poly[N-9"'-hepta-decanyl-2,7-carbazole-alt-5,5-(4',7'-di-2-thienyl-2',1',3'-benzothiad iazole) (PCDTBT) as an electron donor material with the fullerene derivative [6,6]-phenyl $\mathrm{C}_{70}$-butyric acid methyl ester $\left(\mathrm{PC} \mathrm{C}_{70} \mathrm{BM}\right)$ as an acceptor to fabricate a bulk heterojunction solar cell. They also investigated that the internal quantum efficiency was close to $100 \%$ so that essentially every absorbed photon resulted in a separated pair of charge carriers which were collected at the electrodes. Another group of researchers have also reported development of a simple solar cell based on a mixture of fluorinated PTB4 and $\mathrm{PC}_{61} \mathrm{BM}$ with higher than $6 \%$ power conversion efficiency [131]. The best life time recorded by Konarka is more than a year for polymer based PV [132].

\subsection{Photovoltaic fibre attempts}

There are also a significant number of approaches to produce solar cells in fibre form. However, Konarka Technologies, Inc. was the first one who announced and patented the idea of producing a flexible photovoltaic fibre via a continuous process in 2005 [133]. They have used an electrically conductive fibre core which passes through a titania $\left(\mathrm{TiO}_{2}\right)$ suspension and thus coated with the interconnected nanoparticles. The interconnected nanoparticle coated fibre is dried and passed through a dye solution and dried again. The dried fibre is then passed through a polymeric electrolyte and thus coated with the transparent electrode.

Kuraseko et al [134] reported flexible fibre-type poly-Si solar cell. Glass fibre was used in the core of the fibre like photovoltaic structure and p-type poly-Si and n-type poly-Si was deposited onto the core. They studied two different methods; atmospheric thermal CVC and microwave PECVD and the top (TCO) and bottom (metal) electrodes were deposited by thermal evaporation technique. There are also more recent works on the design of OPV based fibres [135-137] and DSSC based fibres [138-140].

\section{A new approach to energy harvesting by Hybrid Piezoelectric- Photovoltaic (HPP) materials}

Renewable energy sources are endless but not available at all times at a given location. For instance, the electrical energy generation by a photovoltaic material is dependent on the light density and the number of photons absorbed by the photoactive layer. If the solar radiation is scarce in a region, for example on a cloudy day, the electrical energy generation 
will be affected. If flexible solar cells are coupled with flexible piezoelectric materials in a combined structure, then the hybrid structure can generate energy from solar radiation as well as mechanical energy, such as wind, rainfall, waves etc.

A novel technology has been developed by Siores et al. [141] that integrates piezoelectric polymer substrate and photovoltaic coating system to create a film or a fibre structure (Figure 12) which is able to transform both mechanical energy (by using the piezoelectric part) and light energy (by using organic photovoltaic part). Since the organic photovoltaic material system is made in a normal atmospheric environment and the usage of ITO is eliminated, the cost associated with the whole structure is manifold less than silicon based photovoltaic. The resultant material system is flexible and can be incorporated in textiles for a wide variety of applications, under different environments on earth, underwater and possibly space.

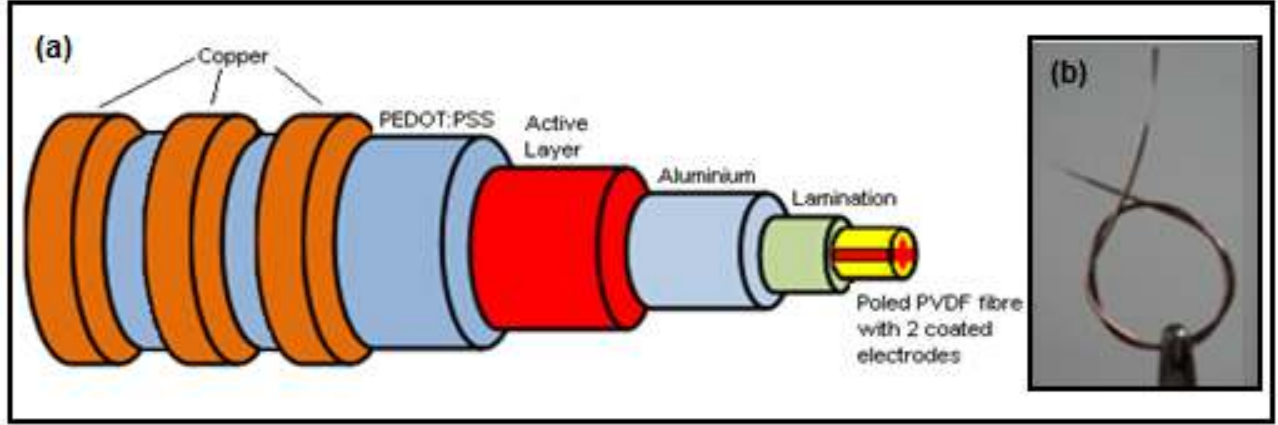

Figure 12. Sketch (a) and photograph (b) of hybrid fibre: OPV cell layers developed onto Al evaporated piezoelectric fibre

The HPP materials are able to produce electrical energy from the environment and provide almost uninterrupted energy generation to power small electronic devices. The flexible HPP structure can be part of any material such as sail, window curtain, tent etc. to generate renewable energy even in the absence of sunlight. One possible configuration for land-based applications of hybrid fibre is a pine tree like structure where the needles are made of HPP fibres. Such a structure may replace the conventional photovoltaic parks that require large panels and sun tracking devices to operate. The surface area that fibres provide is substantially more compared to the solar panels, thus they may be able to generate more energy in a confined area. The tree structure also costs less to manufacture and can harvest energy not only through the photovoltaic but also through the piezoelectric material. Furthermore, the aesthetic aspects of parks incorporating them cannot be overstated. Once flexible fibres are incorporated in textile structures, a plethora of opportunities exist, limited only by the imagination.

Since the HPP structures produce combined piezoelectric technology which converts mechanical energy to fluctuating electrical energy (AC) and organic photovoltaic technology which converts solar energy to constant electrical energy (DC), an associated rectifying circuit consisting of 4 diodes and a capacitor can be used to rectify the fluctuating voltage of 
various frequencies to a constant DC voltage. The constant voltage generated and rectified can then be either stored in an electrical storage device such as batteries and super capacitors or can be utilised on-line directly.

\section{Conclusions}

The term "global warming" has been highlighted more and more every day since it is considered as one of the biggest dangers to life on earth. It is a fact that one of the factors which cause global warming is high carbon emission. Growing population and the increasing technology consumerism contribute to the enhanced usage of energy from coal, oil, electricity etc. However, sooner or later the mankind is anticipated to run out of the coal and oil reserves since they are finite and are not renewable. Energy harvesting properties of both piezoelectric and photovoltaic materials have been known for a long period of time however recently more attention has been paid to produce usable materials for energy generation in the form of electricity to decrease carbon foot print.

Piezoelectric materials can convert almost any kind of mechanical energy to electrical energy. The most suitable piezoelectric material is chosen for a particular application depending on the properties needed. Thus, the maximum energy output, with minimum carbon emission, can be provided to power an electronic device on-line or to be stored. Photovoltaic materials use the biggest energy source to generate green energy and many countries, including Germany and Italy, are well aware of the advantages of using green energy. Furthermore, the increasing solar cell production in general is considerably promising for a cleaner world. Hybrid photovoltaic and piezoelectric structures are capable of converting photons to electrical energy by using photovoltaic part and mechanical energy to electrical energy by using piezoelectric part, in the presence of rain, wind etc, where there is not enough sunlight for photo-conversion. The advantages of the hybrid photovoltaic/piezoelectric materials are their flexibility, light weight, low production cost and the possibility of almost undisturbed energy generation from nature, such as sunlight, wind, rain and other mechanical resources.

The smart materials discussed in this chapter are responsive to many natural resources for green energy generation. The increase in the use of alternative resources for renewable energy can substantially decrease carbon foot print and consequently the effects of global warming.

\section{Author details}

D. Vatansever, E. Siores and T. Shah

University of Bolton, Institute for Materials Research and Innovation, United Kingdom

\section{References}

[1] Flipsen, S.P.J. 2005, "Alternative Power Sources for Portables \& Wearables, Part 1: Power Generation \& Part 2: Energy Storage", Delft University of Technology, ISBN: 90 5155-021-9 / 90-5155-022-7. 
[2] IRAP (Innovative Research and Product) 2008, Piezoelectric Ceramic, Polymer and Ceramic/Polymer Composite Devices - Types, materials, Applications, New Developments, Industry Structure and Global Markets.

[3] Cady, W.G. 1946, "Piezoelectricity", New York: McGraw-Hill, pp. 699.

[4] Ballato, A. 1996, "Piezoelectricity: history and new thrusts", IEEE Proceeding of Ultrasonic Symposium, vol. 13, pp. 575-583.

[5] Curie, J. and Curie, P. 1880, "Development par compression de l'electricite polaire dans les cristaux hemiedres a faces inclinees", Compt. Rend, vol. 91, pp. 383-386.

[6] Lippmann, G. 1881, "Sur le principe de la conversation de l'electricite", Compt. Rend., vol. 92, pp. 1149-1152.

[7] Curie, J. and Curie, P. 1881, "Contractions et dilations produites par des tensions electriques dans les cristaux hemiedres a faces inclinees", Compt. Rend., vol. 93, pp. 11371140.

[8] Minazara, E. and Vasic, D. and Costa, F. 2007 "Piezoelectric Generator Harvesting Bike Vibrations Energy to Supply Portable Devices" Applied Mathematics and Mechanics.

[9] Fukada, E. 1955, "Piezoelectricity of Wood", Journal of the Physical Society of Japan, vol. 108, no. 2, pp. 149.

[10] Bazhenov, V.A. 1961, Piezoelectric properties of wood, Consultant Bureau Enterprises, Inc., New York.

[11] Fukada, E. and Yasuda, I. 1957, "On the Piezoelectric Effect of Bone", Journal of the Physical Society of Japan, vol. 12, no. 10, pp. 1158.

[12] Fukada, E. and Yasuda, I. 1964, "Piezoelectric Effects in Collagen", Japanese Journal of Applied Physics, vol. 3, no. 2, pp. 117.

[13] Fukada, E. 1956, "On the Piezoelectric Effect of Silk Fibers", Journal of the Physical Society of Japan, vol. 11, no. 12, pp. 1301

[14] Yucel, T., Cebe, P. and Kaplan, D.L. 2011, "Structural Origins of Silk Piezoelectricity", Advanced Functional Materials, vol. 21, no. 4, pp. 779-785.

[15] Wang, T., Feng, Z., Song, Y. and Chen, X. 2007, "Piezoelectric properties of human dentin and some influencing factors", Dental materials official publication of the Academy of Dental Materials, vol. 23, no. 4, pp.450-453.

[16] Ueda, H. and Fukada, E. 1971, "Piezoelectricity in Myosin and Actin", Japanese Journal of Applied Physics, vol. 10, no. 11, pp. 1650.

[17] Fukada, E. 1972, "Piezoelectricity in Oriented DNA Films", Journal of Polymer Science Part A-2: Polymer Physics, vol. 10, no. 3.

[18] Duchesne, J., Depireux, J., Bertinchamps, A. , Cornet, N.and van der Kaa, J. M. 1960, "Thermal and electric properties of nucleic acids and proteins", Nature, vol. 188, pp. 405.

[19] Robert, S. 1947, “Dielectric and Piezoelectric properties of Barium Titanate", Phys. Rev. vol. 71, pp. 890-895.

[20] Shirane, G. and Suzuki, K. 1952, "Crystal Structure of Pb(Zr-Ti)Oz", J. Phys. Soc. Jpn., vol. 7, pp. 333.

[21] Shirane, G., Hoshino, S. and Suzuki, K. 1950, "X-ray study of the phase transition in lead titanate", Physical Review, vol. 80, pp. 1105-1106. 
[22] Sawaguchi, E. 1953, "Ferroelectricity versus antiferroelectricity in the solid solutions of $\mathrm{PbZrO}_{3}$ and $\mathrm{PbTiO}_{3}$ ", J. Phys. Soc. Jpn., vol. 8, pp. 615-629.

[23] Jaffe, B., Roth, R.S. and Marzullo, S. 1954, "Piezoelectric Properties of lead zirconatelead titanate solid-solution ceramic ware", J. Appl. Phys., vol. 25, pp. 809-810.

[24] Egerton, L. and Dillon, D. M. 1959, "Piezoelectric and Dielectric Properties of Ceramics in the System Potassium-Sodium Niobate", Journal of the American Ceramic Society, vol. 42, no. 9, pp. 438-442.

[25] Weis, R. S. and Gaylord, T. K. 1985, "Lithium niobate: Summary of physical properties and crystal structure", Applied Physics A: Materials Science \& Processing, vol. 37, no. 4, pp. 191-203.

[26] Smith, R. T. and Welsh, F. S. 1971, "Temperature Dependence of the Elastic, Piezoelectric, and DIelectric Constants of Lithium Tantanate and Lithium Niobate", Journal of Applied Physics, vol. 42, no. 6, pp. 2219-2230.

[27] Kawai, H. 1969, "The piezoelectricity of poly(vinylidene fluoride)", Jpn. J. Appl. Phys., vol. 8, pp. 975-976.

[28] Harrison, J.S. 2001, "Piezoelectric Polymers", NASA/CR-2001-211422, ICASE Report No. 2001-43, pp. 1-26.

[29] Broadhurst, M.G., Davis, G.T., McKinney, J. E. and Collins, R. E. 1978, "Piezoelectricty and pyroelectricity in polyvinylidene flupride-A model", J. Appl. Phys., vol. 49, no. 10, pp. $4992-4997$.

[30] MEAS Piezo 1999, "MEAS Piezo Sensors Technical Manual", Measurement Specialties, Inc. (MEAS, 1999)

[31] Hausler, E. and Stein, L. 1984, "Implantable Physiological Power Supply with PVDF Film", Ferroelectrics, vol. 60, pp. 277-282.

[32] Starner, T. 1996, "Human-powered wearable computing", IBM Systems Journal, vol. 35, no. 3\&4, pp. 618-629.

[33] Kymissis, J., Kendall, C., Paradiso, J. and Gershenfeld, N. 1998, "Parasitic power harvesting in shoes", Digest of Papers. Second International Symposium on Wearable Computers, pp. 132-139.

[34] Shenck, N.S. 1999, "A demonstration of useful electric energy generation from piezoceramics in a shoe", MSc Thesis @ Department of Electrical Engineering and Computer Science, Massachusetts Institute of Technology.

[35] Shenck, N. S. and Paradiso, J. A. 2001, "Energy scavenging with shoe-mounted piezoelectrics", Micro, IEEE, vol. 21, no. 3, pp. 30-42.

[36] Churchill, D.L., Hamel, M.J., Townsend, C. P. and Arms, S. W. 2003, "Strain energy harvesting for wireless sensor networks", Proc. Smart Struct. and Mater. Conf.; Proc. SPIE, vol. 5055, pp. 319-327.

[37] Renaud, M., Sterken, T., Fiorini, P., Puers, R., Baert, K. and van Hoof, C. 2005, "Scavenging energy from human body: design of a piezoelectric transducer", Proc. 13th Int. Conf. on Solid-State Sensors and Actuators and Microsystems, vol. 1, pp. 784-787.

[38] Granstrom, J., Feenstra, J., Sodano, H.A. and Farinholt, K. 2007, "Energy harvesting from a backpack instrumented with piezoelectric shoulder straps", Smart Materials and Structures, vol. 16, no. 5, pp. 1810-1820. 
[39] Swallow, L.M., Luo, J.K., Siores, E., Patel, I. and Dodds, D. 2008, A piezoelectric fibre composite based energy harvesting device for potential wearable applications.

[40] Siores, E. and Swallow, L. 2008, "Apparatus for detection and suppression of muscle tremors", GB Patent No 2444393.

[41] Egusa, S., Wang, Z., Chocat, N., Ruff, Z.M., Stolyarov, A.M., Shemuly, D., Sorin, F., Rakich, P.T. , Joannopoulos, J. D. and Fink, Y. 2010, "Multimaterial piezoelectric fibres", Nat Mater, vol. 9, no. 8, pp. 643-648.

[42] E. Siores, R.L. Hadimani, D. Vatansever, Piezoelectric Polymer Element and Production Method and Apparatus Thereof, U.K. Patent 1015399.7.

[43] Anonymous 2005 "U.S. Department of Energy, Basis Research Needs for Solar Energy Utilization".

[44] Photon International Magazine, March2011

[45] EPIA Global Market Outlook, March2011, visited on 30 th May 2011 http://www.epia.org/publications/photovoltaic-publications-global-market-outlook/gl obal -market-outlook-for-photovoltaics-until-2015.html

[46] Anonymous 1998 "Fundamentals of Photovoltaic Materials" National Solar Power Research Institute, Inc.,pp. 1-10.

[47] Nogueira, M. and Black, A. 2003, "Basics of Solar Electricity: Photovoltaics (PV)", Northern California Solar Energy Resource Guide, , pp. 1-4.

[48] Green, M. 2001, "Third generation photovoltaics: Ultra-high conversion efficiency at low cost", Prog.Photovolt: Res.Appl., vol. 9, no. 2, pp. 123-135.

[49] Chopra, K.L., Paulson, P.D. and Dutta, V. 2004, "Thin-Film Solar Cells: An Overview", Prog. Photovolt: Res. Appl., vol. 12, pp. 69-92.

[50] Gunes, S., Neugebauer, H. and Sariciftci, N. S. 2007, "Conjugated Polymer-Based Organic Solar Cells", Chemical Reviews, vol. 107, pp. 1324-1338.

[51] Li, G., Shrotriya, V., Huang, J., Yao, Y., Moiarty, T., Emery, K. and Yang, Y. 2005, "Highefficiency solution processable polymer photovoltaic cells by self-organization of polymer blends", Nature Materials, vol. 4, pp. 864-868.

[52] Miles, R.W., Zoppi, G. and Forbes, I. 2007, "Inorganic photovoltaic cells", Materials Today, vol. 10, no. 11, pp. 20-27.

[53] Pagliaro, M., Palmisano, G. and Ciriminna, R. 2008, Flexible Solar Cells, WILEY-VCH Verlag GmbH, Weinheim.

[54] Partain, L.D. 1995, Solar Cells and Their Applications, John Wiley \& Sons, New York.

[55] Reuter, M., Brendle, W., Tobail, O. and Werner, J. H. 2009, "50 $\mu \mathrm{m}$ thin solar cells with 17.0\% efficiency", Solar Energy Materials and Solar Cells, vol. 93, no. 6-7, pp. 704-706.

[56] Wang, A., Zhao, J., Wenham, S.R. and Green, M.A. 1996, "21.5\% Efficient thin silicon solar cell", Progress in Photovoltaics: Research and Applications, vol. 4, no. 1, pp. 55-58.

[57] Chopra, K.L., Paulson, P.D. and Dutta, V. 2004, "Thin-Film Solar Cells: An Overview", Prog. Photovolt: Res. Appl., vol. 12, pp. 69-92.

[58] Sariciftci, N.S. 1999, "Polymeric photovoltaic materials", Current Opinion in Solid State and Materials Science, vol. 4, no. 4, pp. 373-378. [59] 
[59] Cai, W. , Gong, X. and Cao, Y. 2010, "Polymer solar cells: Recent development and possible routes for improvement in the performance", Solar Energy Materials and Solar Cells, vol. 94, no. 2, pp. 114-127.

[60] Li, G., Shrotriya, V., Yao, Y., Huang, J. and Yang, Y. 2007, "Manipulating regioregular poly(3-hexylthiophene) : [6,6]-phenyl-C61-butyric acid methyl ester blends-route towards high efficiency polymer solar cells", Journal of Materials Chemistry, vol. 17, no. 30, pp. 3126-3140.

[61] Cozzens, R.F. 1982, in Electrical Properties of Polymers, ed. D.A. Seanor, Academic Press, New York, pp. 93.

[62] Ameri, T., Dennler, G., Waldauf, C., Denk, P., Forberich, K., Scharber, M.C., Brabec, C.J. and Hingerl, K. 2008, "Realization, characterization, and optical modeling of inverted bulk-heterojunction organic solar cells", Journal of Applied Physics, vol. 103, no. 8, pp. 084506.

[63] Liang, Y., Wu, Y., Feng, D., Tsai, S.-., Son, H.-. and Li, G. and Yu, L. 2008; 2009, "Development of New Semiconducting Polymers for High Performance Solar Cells", Journal of the American Chemical Society, vol. 131, no. 1, pp. 56-57.

[64] Singh, T.B., Marjanović, N., Matt, G.J., Günes, S., Sariciftci, N.S., Montaigne Ramil, A., Andreev, A., Sitter, H., Schwödiauer, R. and Bauer, S. 2005, "High-mobility n-channel organic field-effect transistors based on epitaxially grown C60 films", Organic Electronics, vol. 6, no. 3, pp. 105-110.

[65] Gerischer, H., Michel-Beyerle, M.E., Rebentrost, F. and Tributsch, H. 1968, "Sensitization of charge injection into semiconductors with large band gap", Electrochimica Acta, vol. 13, no. 6, pp. 1509-1515.

[66] Tributsch, H. 1972, "Reaction of Excited Chorophyll Molecules at Electrodes and in Photosynthesis", Photochem.Photobiol, vol. 16, pp. 261-269.

[67] Hagfeldt, A., Boschloo, G., Sun, L., Kloo, L. and Pettersson, H. 2010, "Dye-Sensitized Solar Cells", Chemical reviews, vol. 110, no. 11, pp. 6595-6663.

[68] Gratzel, M. 2005, "Solar Energy Conversion by Dye-Sensitized Photovoltaic Cells", Inorganic chemistry, vol. 44, no. 20, pp. 6841-6851.

[69] Cahen, D., Hodes, G., Gratzel, M., Guillemoles, J.F. and Riess, I. 2000, "Nature of Photovoltaic Action in Dye-Sensitized Solar Cells", The Journal of Physical Chemistry B, vol. 104, no. 9, pp. 2053-2059.

[70] Wang, X., Zhi, L. and Mullen, K. 2008, "Transparent, Conductive Graphene Electrodes for Dye-Sensitized Solar Cells", Nano Letters, vol. 8, no. 1, pp. 323-327.

[71] Calogero, G., Calandra, P., Irrera, A., Sinopoli, A., Citro, I. and Di Marco, G. 2011, "A new type of transparent and low cost counter-electrode based on platinum nanoparticles for dye-sensitized solar cells", Energy \& Environmental Science, vol. 4, no. 5, pp. 1838-1844.

[72] Wang, P., Zakeeruddin, S.M., Comte, P., Exnar, I. and Gratzel, M. 2003, "Gelation of Ionic Liquid-Based Electrolytes with Silica Nanoparticles for Quasi-Solid-State DyeSensitized Solar Cells", Journal of the American Chemical Society, vol. 125, no. 5, pp. 11661167. 
[73] Gratzel, M. 2005, "Solar Energy Conversion by Dye-Sensitized Photovoltaic Cells", Inorganic chemistry, vol. 44, no. 20, pp. 6841-6851.

[74] Bach, U., Lupo, D., Comte, P., Moser, J.E., Weissortel, F., Salbeck, J., Spreitzer, H. and Gratzel, M. 1998, "Solid-state dye-sensitized mesoporous TiO2 solar cells with high photon-to-electron conversion efficiencies", Nature, vol. 395, no. 6702, pp. 583-585.

[75] Han, L., Fukui, A., Chiba, Y., Islam, A., Komiya, R., Fuke, N., Koide, N., Yamanaka, R. and Shimizu, M. 2009, "Integrated dye-sensitized solar cell module with conversion efficiency of 8.2\%", Applied Physics Letters, vol. 94, no. 1, pp. 013305.

[76] Law, M., Greene, L.E., Johnson, J.C., Saykally, R. and Yang, P. 2005, "Nanowire dyesensitized solar cells", Natural Materials, vol. 4, pp. 455-459.

[77] Horiuchi, T., Miura, H., Sumioka, K. and Uchida, S. 2004, "High Efficiency of DyeSensitized Solar Cells Based on Metal-Free Indoline Dyes", Journal of the American Chemical Society, vol. 126, no. 39, pp. 12218-12219.

[78] Chiba, Y., Islam, A., Watanabe, Y., Komiya, R., Koide, N. and Han, L. 2006 "DyeSensitized Solar Cells with Conversion Efficiency of 11.1\%", Japanese Journal of Applied Physics, vol. 45, no. 25, pp. L638.

[79] Wanlass, M.W., Coutts, T.J., Ward, J.S., Emery, K.A., Gessert, T.A. and Osterwald, C.R. 1991, "Advanced high-efficiency concentrator tandem solar cells", IEEE Preceeding on Photovoltaic Specialists Conference, 07th-11th October, pp. 38.

[80] De Vos, A. 1980, "Detailed balance limit of the efficiency of tandem solar cells", J. Phys. D: Appl. Phys., vol. 13, pp. 839-846.

[81] Green, M.A., Emery, K., Hisikawa, Y. and Warta, W. 2007, "Solar cell efficiency tables (version 30)", Progress in Photovoltaics: Research and Applications, vol. 15, no. 5, pp. 425430.

[82] Geisz, J.F., Kurtz, S., Wanlass, M.W., Ward, J.S., Duda, A., Friedman, D.J., Olson, J.M., McMahon, W.E., Moriarty, T.E. and Kiehl, J.T. 2007, "High-efficiency $\mathrm{GaInP} / \mathrm{GaAs} / \mathrm{InGaAs}$ triple-junction solar cells grown inverted with a metamorphic bottom junction", Applied Physics Letters, vol. 91, no. 2, pp. 023502-3.

[83] Dennler, G., Scharber, M.C., Ameri, T., Denk, P., Forberich, K., Waldauf, C. and Brabec, C.J. 2008, "Design Rules for Donors in Bulk-Heterojunction Tandem Solar Cells: Towards 15 \% Energy-Conversion Efficiency", Advanced Materials, vol. 20, no. 3, pp. 579583.

[84] Gunes, S. and Sariciftci, N. S. 2008, "Hybrid solar cells", Inorganica Chimica Acta, vol. 361, no. 3, pp. 581-588.

[85] van Hal, P.A., Wienk, M.M., Kroon, J.M., Verhees, W.J.H., Slooff, L.H., van Gennip, W. J. H., van Gennip, W. J. H. and Janssen, R.A.J. 2003, "Photoinduced Electron Transfer and Photovoltaic Response of a MDMO-PPV:TiO2 Bulk-Heterojunction", Advanced Materials, vol. 15, no. 2, pp. 118-121.

[86] McDonald, S.A., Konstantatos, G., Zhang, S., Cyr, P.W., Klem, E.J.D., Levina, L. and Sargent, E.H. 2005, "Solution-processed PbS quantum dot infrared photodetectors and photovoltaics", Nat Mater, vol. 4, no. 2, pp. 138-142.

[87] Zhang, S., Cyr, P.W., McDonald, S.A., Konstantatos, G. and Sargent, E.H. 2005, "Enhanced infrared photovoltaic efficiency in $\mathrm{PbS}$ nanocrystal/semiconducting polymer 
composites: 600-fold increase in maximum power output via control of the ligand barrier", Applied Physics Letters, vol. 87, no. 23, pp. 233101.

[88] Beek, W.J.E., Wienk, M.M. and Janssen, R.A.J. 2006, "Hybrid Solar Cells from Regioregular Polythiophene and ZnO Nanoparticles", Adv. Funct. Mater., vol. 16, no. 8, pp. 1112-1116.

[89] Olson, D.C., Piris, J., Collins, R.T., Shaheen, S.E. and Ginley, D.S. 2006, "Hybrid photovoltaic devices of polymer and ZnO nanofiber composites", Thin Solid Films, vol. 496, no. 1, pp. 26-29.

[90] Greenham, N.C., Peng, X. and Alivisatos, A.P. 1996, "Charge separation and transport in conjugated-polymer/semiconductor-nanocrystal composites studied by photoluminescence quenching and photoconductivity", Physical Review B, vol. 54, no. 24, pp. 17628-17637.

[91] Ginger, D.S. and Greenham, N.C. 1999, "Photoinduced electron transfer from conjugated polymers to CdSe nanocrystals", Physical Review B, vol. 59, no. 16, pp. 1062210629.

[92] Huynh, W.U., Dittmer, J.J. and Alivisatos, A.P. 2002, "Hybrid Nanorod-Polymer Solar Cells", Science, vol. 295, no. 5564, pp. 2425-2427.

[93] Gur, I., Fromer, N.A., Geier, M.L. and Alivisatos, A.P. 2005, "Air-Stable All-Inorganic Nanocrystal Solar Cells Processed from Solution", Science, vol. 310, no. 5747, pp. $462-$ 465.

[94] Arici, E., Sariciftci, N.S. and Meissner, D. 2003, "Hybrid Solar Cells Based on Nanoparticles of CuInS2 in Organic Matrices", Advanced Functional Materials, vol. 13, no. 2, pp. 165-171.

[95] Chapin, D.M., Fuller, C.S. and Pearson, G.L. 1954, "A New Silicon pin Junction Photocell for Converting Solar Radiation into Electrical Power", Journal of Applied Physics, vol. 25, no. 5, pp. 676.

[96] Chopra, K.L., Paulson, P.D. and Dutta, V. 2004, "Thin-Film Solar Cells: An Overview", Prog. Photovolt: Res. Appl., vol. 12, pp. 69-92.

[97] Spanggaard, H. and Krebs, F. C. 2004, "A brief history of the development of organic and polymeric photovoltaics", Solar Energy Materials and Solar Cells, vol. 83, no. 2-3, pp. 125-146.

[98] Sariciftci, N., Smilowitz, L.B., Zhang, C., Srdanov, V.I., Heeger, A.J. and Wudl, F. 1993a, "Photoinduced electron transfer from conducting polymers onto Buckminsterfullerene", Proceedings of SPIE, vol. 1852, no. 1, pp. 297.

[99] Sariciftci, N.S., Smilowitz, L., Heeger, A.J. and Wudl, F. 1993b, "Semiconducting polymers (as donors) and buckminsterfullerene (as acceptor): photoinduced electron transfer and heterojunction devices", Synthetic Metals, vol. 59, no. 3, pp. 333-352.

[100] Sariciftci, N.S. and Heeger, A.J. 1994, Conjugated Polymer-Acceptor Heterojunctions; Diodes, Photodiodes, and Photovoltaic Cells, 5,331,183, California, USA.

[101] Sariciftci, N. and Heeger, A.J. 1995, "Role of buckminsterfullerene, C60, in organic polymeric photoelectric devices", Proceedings of SPIE, vol. 2530, no. 1, pp. 76. 
[102] Yu, G., Gao, J., Hummelen, J.C., Wudl, F. and Heeger, A.J. 1995, "Polymer Photovoltaic Cells: Enhanced Efficiencies via a Network of Internal Donor-Acceptor Heterojunctions", Science, vol. 270, no. 5243, pp. 1789-1791.

[103] Morita, S., Kiyomatsu, S., Yin, X.H., Zakhidov, A.A., Noguchi, T., Ohnishi, T. and Yoshino, K. 1993, "Doping effect of buckminsterfullerene in poly(2,5-dialkoxy-pphenylene vinylene)", Journal of Applied Physics, vol. 74, no. 4, pp. 2860.

[104] Brabec, C., Schilinsky, P. and Waldauf, C. 2007, Method for Treating a Photovoltaic Active Layer and Organic Photovoltaic Element, 7,306, edn, Lowel, MA, USA.

[105] Brabec, C.J., Shaheen, S.E., Winder, C. and Sariciftci, N. S. and Denk, P. 2002, "Effect of $\mathrm{LiF} /$ metal electrodes on the performance of plastic solar cells", Applied Physics Letters, vol. 80, no. 7, pp. 1288-1290.

[106] Blom, P.W.M., de Jong, M. J. M. and Breedijk, S. 1997, "Temperature dependent electron-hole recombination in polymer light-emitting diodes", Applied Physics Letters, vol. 71, no. 7, pp. 930-932.

[107] Melzer, C., Koop, E.J., Mihailetchi, V.D. and Blom, P.W.M. 2004, "Hole Transport in Poly(phenylene vinylene)/Methanofullerene Bulk-Heterojunction Solar Cells", Advanced Functional Materials, vol. 14, no. 9, pp. 865-870.

[108] Mihailetchi, V.D., Koster, L.J.A., Blom, P.W.M., Melzer, C., Boer, B., Duren, J.K.J. and Janssen, R.A.J. 2005, "Compositional Dependence of the Performance of Poly(pphenylene vinylene):Methanofullerene Bulk-Heterojunction Solar Cells", Advanced Functional Materials, vol. 15, no. 5, pp. 795-801.

[109] Schilinsky, P., Waldauf, C. and Brabec, C.J. 2002, "Recombination and loss analysis in polythiophene based bulk heterojunction photodetectors", Applied Physics Letters, vol. 81, no. 20, pp. 3885-3887.

[110] Li, G., Shrotriya, V., Huang, J., Yao, Y., Moiarty, T., Emery, K. and Yang, Y. 2005, "High-efficiency solution processable polymer photovoltaic cells by self-organization of polymer blends", Nature Materials, vol. 4, pp. 864-868.

[111] Padinger, F., Rittberger, R.S. and Sariciftci, N.S. 2003, "Effects of Postproduction Treatment on Plastic Solar Cells", Advanced Functional Materials, vol. 13, no. 1, pp. 85-88.

[112] Kim, Y., Choulis, S.A., Nelson, J., Bradley, D.D.C., Cook, S. and Durrant, J.R. 2005, "Device annealing effect in organic solar cells with blends of regioregular poly(3hexylthiophene) and soluble fullerene", Applied Physics Letters, vol. 86, no. 6, pp. 0635023.

[113] Shrotriya, V., Ouyang, J., Tseng, R.J. \& Li, G. and Yang, Y. 2005, "Absorption spectra modification in poly(3-hexylthiophene):methanofullerene blend thin films", Chemical Physics Letters, vol. 411, no. 1-3, pp. 138-143.

[114] Reyes-Reyes, M., Kim, K., Dewald, J., LÃ³ pez-Sandoval, R., Avadhanula, A., Curran, S. and Carroll, D.L. 2005, "Meso-Structure Formation for Enhanced Organic Photovoltaic Cells", Organic letters, vol. 7, no. 26, pp. 5749-5752.

[115] Ma, W., Yang, C., Gong, X., Lee, K. and Heeger, A.J. 2005, "Thermally Stable, Efficient Polymer Solar Cells with Nanoscale Control of the Interpenetrating Network Morphology", Advanced Functional Materials, vol. 15, no. 10, pp. 1617-1622. 
[116] Kim, Y., Cook, S., Tuladhar, S.M., Choulis, S.A., Nelson, J., Durrant, J.R., Bradley, D.D.C., Giles, M., McCulloch, I., Ha, C.-. and Ree, M. 2006, "A strong regioregularity effect in self-organizing conjugated polymer films and high-efficiency polythiophene:fullerene solar cells", Nat Mater, vol. 5, no. 3, pp. 197-203.

[117] Yang, X., Loos, J., Veenstra, S.C., Verhees, W.J.H., Wienk, M.M., Kroon, J.M., Michels, M.A.J. and Janssen, R.A.J. 2005, "Nanoscale Morphology of High-Performance Polymer Solar Cells", Nano Letters, vol. 5, no. 4, pp. 579-583.

[118] Ma, W., Yang, C., Gong, X., Lee, K. and Heeger, A.J. 2005, "Thermally Stable, Efficient Polymer Solar Cells with Nanoscale Control of the Interpenetrating Network Morphology", Advanced Functional Materials, vol. 15, no. 10, pp. 1617-1622.

[119] Yang, X., Loos, J., Veenstra, S.C., Verhees, W.J.H., Wienk, M.M., Kroon, J.M., Michels, M.A.J. and Janssen, R.A.J. 2005, "Nanoscale Morphology of High-Performance Polymer Solar Cells", Nano Letters, vol. 5, no. 4, pp. 579-583.

[120] Savenije, T.J., Kroeze, J.E., Yang, X. and Loos, J. 2005, "The Effect of Thermal Treatment on the Morphology and Charge Carrier Dynamics in a Polythiophene-Fullerene Bulk Heterojunction", Advanced Functional Materials, vol. 15, no. 8, pp. 1260-1266.

[121] Padinger, F., Rittberger, R.S. and Sariciftci, N.S. 2003, "Effects of Postproduction Treatment on Plastic Solar Cells", Advanced Functional Materials, vol. 13, no. 1, pp. 85-88.

[122] Li, G., Shrotriya, V., Huang, J., Yao, Y., Moiarty, T., Emery, K. and Yang, Y. 2005, "High-efficiency solution processable polymer photovoltaic cells by self-organization of polymer blends", Nature Materials, vol. 4, pp. 864-868.

[123] Wang, W., Wu, H., Yang, Y., Luo, C., Zhang, Y., Chen, J. and Cao, Y. 2007, "Highefficiency polymer photovoltaic devices from regioregular-poly(3-hexylthiophene-2,5diyl) and [6,6]-phenyl-C61-butyric acid methyl ester processed with oleic acid surfactant", Applied Physics Letters, vol. 90, no. 18, pp. 183512.

[124] Berson, S., De Bettignies, R., Bailly, S. and Guillerez, S. 2007, "Poly(3-hexylthiophene) Fibers for Photovoltaic Applications", Advanced Functional Materials, vol. 17, no. 8, pp. 1377-1384.

[125] Moule, A. J. and Meerholz, K. 2008, "Controlling Morphology in Polymer-Fullerene Mixtures", Advanced Materials, vol. 20, no. 2, pp. 240-245.

[126] Li, G., Shrotriya, V., Yao, Y., Huang, J. and Yang, Y. 2007, "Manipulating regioregular poly(3-hexylthiophene) : [6,6]-phenyl-C61-butyric acid methyl ester blends-route towards high efficiency polymer solar cells", Journal of Materials Chemistry, vol. 17, no. 30, pp. 3126-3140.

[127] Dennler, G., Scharber, M. C. and Brabec, C. J. 2009, "Polymer-Fullerene BulkHeterojunction Solar Cells", Adv Mater, vol. 21, pp. 1323-1338.

[128] Shrotriya, V., Ouyang, J., Tseng, R.J. \& Li, G. and Yang, Y. 2005, "Absorption spectra modification in poly(3-hexylthiophene):methanofullerene blend thin films", Chemical Physics Letters, vol. 411, no. 1-3, pp. 138-143.

[129] Chirvase, D., Parisi, J., Hummelen, J.C. and Dyakonov, V. 2004, Influence of nanomorphology on the photovoltaic action of polymer - fullerene composites. 
[130] Park, S.H., Roy, A., Beaupre, S., Cho, S., Coates, N., Moon, J.S., Moses, D., Leclerc, M., Lee, K. and Heeger, A.J. 2009, "Bulk heterojunction solar cells with internal quantum efficiency approaching 100\%", Nat Photon, vol. 3, no. 5, pp. 297-302.

[131] Liang, Y., Feng, D., Wu, Y., Tsai, S.-., Li, G., Ray, C. and Yu, L. 2009, "Highly Efficient Solar Cell Polymers Developed via Fine-Tuning of Structural and Electronic Properties", Journal of the American Chemical Society, vol. 131, no. 22, pp. 7792-7799.

[132] Hauch, J.A., Schilinsky, P., Choulis, S.A., Childers, R., Biele, M. and Brabec, C.J. 2008, Flexible organic P3HT:PCBM bulk-heterojunction modules with more than 1 year outdoor lifetime", Solar Energy Materials and Solar Cells, vol. 92, no. 7, pp. 727-731.

[133] Chittibabu, K., Eckert, R., Gaudiana, R., Li, L., Montello, A., Montello, E. and Wormser, P. 2005, Photovoltaic Fibers, 6,913,713 edn, USA.

[134] Kuraseko, H., Nakamura, T., Toda, S., Koaizawa, H., Jia, H. and Kondo, M. 2006, Development of flexible fiber-type poly-Si solar cell", Conference Record of the 2006 IEEE 4th World Conference on Photovoltaic Energy Conversion, pp. 1380.

[135] Li, Y., Zhou, W., Xue, D., Liu, J., Peterson, E.D., Nie, W. and Carroll, D. L. 2009, Origins of performance in fiber-based organic photovoltaics", Applied Physics Letters, vol. 95, no. 20, pp. 203503-3.

[136] O'Connor, B., Pipe, K. P. and Shtein, M. 2008, "Fiber based organic photovoltaic devices", Applied Physics Letters, vol. 92, no. 19, pp. 193306-3.

[137] Bedeloglu, A., Demir, A. and Bozkurt, Y. and Sariciftci, N. S. 2010, "A Photovoltaic Fiber Design for Smart Textiles", Textile Research Journal, vol. 80, no. 11, pp. 1065-1074.

[138] Toivola, M., Ferenets, M., Lund, P. and Harlin, A. 2009, "Photovoltaic fiber", Thin Solid Films, vol. 517, no. 8, pp. 2799-2802.

[139] Baps, B., Eber-Koyuncu, M. and Koyuncu, M. 2002, "Ceramic Based Solar Cells in Fiber Form", Key Engineering Materials, vol. 206-213, pp. 937-940.

[140] Ramier, J., Plummer, C.J.G., Leterrier, Y., Månson, J.-.E., Eckert, B. and Gaudiana, R. 2008, "Mechanical integrity of dye-sensitized photovoltaic fibers", Renewable Energy, vol. 33, no. 2, pp. 314-319.

[141] Siores, E., Hadimani, R.L. and Vatansever, D. 2010, "Hybrid Energy Conversion Device", GB Patent No. 1016193.3. 